\title{
Studies on the Golgi Apparatus
}

\author{
CUMULATIVE INHIBITION OF PROTEIN AND GLYCOPROTEIN \\ SECRETION BY D-GALACTOSAMINE
}

\author{
By CHRISTIAN H. BAUER, RAINER LUKASCHEK and WERNER G. REUTTER \\ Biochemisches Institut, Universität Freiburg, 78 Freiburg, Germany
}

(Received 21 December 1973)

\begin{abstract}
1. The administration of D-galactosamine leads to inhibition of protein and glycoprotein secretion by rat liver. To test the secretory function, the secretion times for galactoseand fucose-containing glycoproteins were determined; they were lengthened from 6 to $9 \mathrm{~min}$ and from 8 to $13 \mathrm{~min}$ respectively. 2. The Golgi apparatus was enriched 100-120fold relative to the homogenate. A new linked-assay system for the marker enzyme, UDP-galactose- $N$-acetyl-D-glucosamine galactosyltransferase, is presented. The activity of the enzyme was measured spectrophotometrically by following the formation of UDP coupled to nicotinamide nucleotide reduction. The Michaelis constants were calculated to be $0.11 \mathrm{~mm}$ for UDP-galactose with $N$-acetyl-D-glucosamine as exogenous acceptor and $19 \mathrm{~mm}$ for $N$-acetyl-D-glucosamine itself. 3. The physiological substrate of the galactosyltransferase, UDP-galactose, can be replaced by UDP-galactosamine, which accumulates after D-galactosamine administration. Under conditions in vitro the rate of D-galactosamine transfer to an endogenous acceptor protein of the Golgi fraction reaches $9 \%$ of that with D-galactose; this finding is noteworthy, because normally a non-acetylated amino sugar does not occur in glycoproteins. 4 . The albumin content of the Golgi-rich fraction was diminished to $55 \%$ of the reference value $6 \mathrm{~h}$ after the injection of $375 \mathrm{mg}$ of $\mathrm{D}$-galactosamine hydrochloride/ $\mathrm{kg}$ body wt. The transfer of $\mathrm{D}-\left[1-{ }^{14} \mathrm{C}\right]$ galactose to an endogenous acceptor protein fell to $60 \%$ compared with Golgirich fractions from untreated animals. Analysis of the Golgi-rich fraction by polyacrylamide-gel electrophoresis showed a decrease or loss of several protein bands. 5. Protein synthesis can be restored by up to $80 \%$ if the UTP pool, decreased after D-galactosamine administration, is filled up by several injections of uridine. 6 . From the results presented it can be concluded that the disturbed secretion of proteins and glycoproteins was due to a cumulative effect of galactosamine by: $(a)$ inhibition of protein synthesis leading to a diminution of the endogenous acceptor pool of the galactosyltransferase; $(b)$ inhibition of the galactosyltransferase activity by galactosamine metabolites and $(c)$ replacement of UDP-galactose by UDP-galactosamine.
\end{abstract}

It is well established that the Golgi apparatus is involved in the synthesis and secretion of lipo- and glyco-proteins (Caro \& Palade, 1964; Maley et al., 1969; Rambourg et al., 1969; Morré et al., 1971). Radioautographic studies on the uptake of ${ }^{3} \mathrm{H}$ labelled galactose showed the preferential incorporation of radioactivity into the Golgi region of various cells secreting glycoproteins (Neutra \& Leblond, 1966). The discovery of specific glycosyltransferases in the Golgi apparatus (Wagner \& Cynkin, 1969a; Fleischer et al., 1969) strongly supports the significance of this site in glycosylation of proteins. It is assumed that the first sugar attached, $N$-acetyl-Dglucosamine (Molnar et al., 1965; Lawford \& Schachter, 1966), is transferred directly to the nascent glycoprotein at the rough endoplasmic reticulum, whereas D-mannose (Caccam et al., 1969), additional molecules of $N$-acetyl-D-glucosamine
(Wagner \& Cynkin, 1969b; Tetas et al., 1970), D-galactose (Hagopian et al., 1968; Fleischer et al., 1969), L-fucose (Haddad et al., 1971) and $N$-acetylD-neuraminic acid (Hudgin et al., 1971) are incorporated at the smooth endoplasmic reticulum, including the Golgi apparatus.

During the induction of galactosamine hepatitis (Reutter et al., 1968; Keppler et al., 1968; Lesch et al., 1970), morphological alterations of the endoplasmic reticulum were observed (Medline $e t$ al., 1970) and alterations of glycoprotein synthesis found (Reutter et al., 1969). In order to study these effects in more detail, we investigated the influence of D-galactosamine on the function and composition of the Golgi apparatus. An early event after Dgalactosamine administration is the accumulation of D-galactosamine metabolites, galactosamine 1phosphate, UDP-hexosamines, $N$-acetylhexosamine 
phosphates, UDP- $N$-acetylhexosamines (Keppler \& Decker, 1969; Bauer et al., 1972). The metabolism of D-galactosamine is accompanied by a marked decrease in UTP+UDP, UDP-glucose and UDPgalactose (Keppler \& Decker, 1969; Keppler et al., 1970a). UDP-galactose is the substrate for the galactosyltransferase (Morré et al., 1969; Wagner \& Cynkin, 1971), for which a new linked-assay system is described. Data show that the administration of D-galactosamine leads to an inhibition of protein and glycoprotein secretion, which is due to a cumulative effect.

\section{Materials and Methods}

\section{Animals}

Male Wistar rats (Ivanovas, Kisslegg, Germany), weighing about $180 \mathrm{~g}$ each, were fed on a commercial diet (Altromin; Altromin G.m.b.H., Lage-Lippe, Germany) and given water ad libitum. The diet contained $18-20 \%(w / w)$ protein. The animals were kept in a room with natural lighting supplemented by overhead fluorescent lights during daytime.

\section{Chemicals}

D-Galactosamine hydrochloride (puriss.) and $N$ acetyl-D-glucosamine were purchased from C. Roth OHG (Karlsruhe, Germany). The purity was checked by ion-exchange chromatography with an amino acid analyser (Biocal model 200) (Bauer et al., 1972) and paper electrophoresis in $0.1 \mathrm{M}$-sodium borate buffer, pH 8.8.

$\mathrm{D}-\left[1-{ }^{14} \mathrm{C}\right]$ Galactosamine $(2.7 \mathrm{mCi} / \mathrm{mmol})$, UDP$\left[{ }^{14} \mathrm{C}\right]$ galactose $(245 \mathrm{mCi} / \mathrm{mmol}), \quad \mathrm{L}-\left[1-{ }^{14} \mathrm{C}\right]$ leucine $(61 \mathrm{mCi} / \mathrm{mmol})$ and $\left[{ }^{14} \mathrm{C}\right]$ toluene were obtained from The Radiochemical Centre, Amersham, Bucks., U.K. D- $\left[1-{ }^{14} \mathrm{C}\right]$ Galactosamine 1-phosphate and UDP-D-[1- $\left.{ }^{14} \mathrm{C}\right]$ galactosamine were prepared enzymically in vitro or in vivo as described (Bauer et al., 1972; Bauer \& Reutter, 1973).

The enzymes UDP-glucose-NAD ${ }^{+}$oxidoreductase (EC 1.1.1.22), ATP-nucleoside diphosphate phosphotransferase (EC 2.7.4.6), and UTP- $\alpha$-D-glucose 1-phosphate uridylyltransferase (EC 2.7.7.9), and the coenzymes ATP, NAD ${ }^{+}$and the substrate glucose 1-phosphate were supplied by Boehringer Mannheim G.m.b.H. (Mannheim, Germany). UDPgalactose came from Sigma Chemical Co. (St. Louis, Mo., U.S.A.). 2-(p-Iodophenyl)-3-(p-nitrophenyl)-5phenyltetrazolium chloride was bought from $T$. Schuchardt (München, Germany), and bovine serum albumin (electrophoretic purity $100 \%$ ) from Behringwerke A.G. (Marburg-Lahn, Germany). Radiochemically pure rat albumin was a kind gift from Dr. G. Schreiber, Biochemisches Institut der Universität Freiburg, Germany (Schreiber et al.,
1969). All other chemicals of analytical grade were obtained from E. Merck A.G. (Darmstadt, Germany).

\section{Methods}

Measurement of glycoprotein secretion. Schreiber et al. $(1969,1971)$ have described a method of determining the kinetics of serum protein secretion. This procedure was modified by replacing the radioactive labelled amino acid by $\mathrm{D}-\left[1-{ }^{14} \mathrm{C}\right]$ galactose or $\mathrm{L}-\left[{ }^{3} \mathrm{H}\right]$ fucose (Reutter, 1971). At 5 or $6 \mathrm{~h}$ before the intravenous injection of $100 \mu \mathrm{Ci}$ of $\mathrm{D}-\left[1{ }^{14} \mathrm{C}\right]$ galactose or $100 \mu \mathrm{Ci}$ of $\mathrm{L}-\left[{ }^{3} \mathrm{H}\right]$ fucose $/ \mathrm{kg}$ body wt., $375 \mathrm{mg}$ of D-galactosamine hydrochloride/ $\mathrm{kg}$ body wt. was administered intraperitoneally. Blood samples $(0.2 \mathrm{ml}$ each) were withdrawn from the caval vein at timed intervals while the animals were under pentobarbital anaesthesia. The protein-bound radioactivity was determined as described by Mans \& Novelli (1960). The specific radioactivity of glycoproteins was plotted as a function of time. The time between the injection of labelled D-galactose or L-fucose and the appearance of labelled glycoproteins in the serum is called 'galactose-time' or 'fucose-time' respectively.

Preparation of a Golgi-rich fraction. Methods for the isolation of the Golgi apparatus have been described in detail by several authors (Morré et al., 1969; Fleischer et al., 1969). This procedure is partly based on techniques developed by Morré et al. (1969) and Leelavathi et al. (1970). The livers were perfused in situ with $25 \mathrm{ml}$ of $0.15 \mathrm{M}-\mathrm{NaCl}$ solution while the animals were under ether anaesthesia. All subsequent operations were carried out at $4^{\circ} \mathrm{C}$. The livers were squeezed through a sieve (sieve pore $0.8 \mathrm{~mm}$ diam.) to remove the connective tissue. The minced liver $(10 \mathrm{~g})$ was suspended in $5 \mathrm{vol}$. of $0.5 \mathrm{M}$-sucrose containing $0.1 \mathrm{M}-\mathrm{Tris}-\mathrm{HCl}$ buffer $(\mathrm{pH} 7.0)$ and $0.5 \%(\mathrm{w} / \mathrm{v})$ dextran T-500, followed by homogenization for $30-40$ s at slow speed in a Torpedo homogenizer (Emmendinger Maschinenbau G.m.b.H., Emmendingen, Germany), equipped with a thyristor regulator (Janke \& Kunkel KG, Staufen, Germany). The mixture was centrifuged for $15 \mathrm{~min}$ at $400 \mathrm{~g}$, the supernatant collected and centrifuged at $16000 \mathrm{~g}$ for $30 \mathrm{~min}$. Then the sediments were carefully suspended in $16 \mathrm{ml}$ of $1.6 \mathrm{M}$-sucrose buffer with 10 strokes of a Dounce homogenizer with a type $L$ pestle. A portion $(8 \mathrm{ml})$ of this suspension was placed in the bottom of an SW 27 cellulose nitrate tube and overlaid with the following step gradient: $5 \mathrm{ml}$ of $1.25 \mathrm{M}$-sucrose, $6 \mathrm{ml}$ of $1.0 \mathrm{M}$-sucrose, $8 \mathrm{ml}$ of $0.95 \mathrm{M}$-sucrose, $5 \mathrm{ml}$ of $0.9 \mathrm{M}$-sucrose, and finally $5 \mathrm{ml}$ of $0.5 \mathrm{M}$-sucrose. All gradient solutions were prepared in $0.1 \mathrm{M}$-Tris- $\mathrm{HCl}$ buffer (pH7.0) and $0.5 \%(\mathrm{w} / \mathrm{v})$ dextran. According to Morré et al. (1971) the addition of bivalent cations is not essential for the isolation of the Golgi apparatus and therefore no $\mathrm{Ca}^{2+}, \mathrm{Mg}^{2+}$ or $\mathrm{Mn}^{2+}$ ions were added to the homogenization medium and gradient 
solutions. The density of the solutions was controlled with a Zeiss refractometer (C. Zeiss, Oberkochen, Germany). The gradient was centrifuged for $90 \mathrm{~min}$ at $25000 \mathrm{rev} . / \mathrm{min}\left(82000 \mathrm{~g}_{\mathrm{av} .}\right)$ in an SW 27 rotor. The Golgi-rich fraction was localized mainly at the 0.95 and $0.9 \mathrm{M}$-sucrose interface. The membranes were removed from the gradient by using a pipette fitted with a rubber aspirator, washed once in Tris$\mathrm{HCl}$ buffer and were collected after centrifugation at $10000 \mathrm{~g}$ for $10 \mathrm{~min}$.

To investigate the influence of D-galactosamine on the Golgi apparatus, the rats received a single injection of $375 \mathrm{mg}$ of $\mathrm{D}$-galactosamine hydrochloride $(1.74 \mathrm{mmol}) / \mathrm{kg}$ body wt. and were killed 3,6 or $12 \mathrm{~h}$ thereafter. For incorporation studies 100 or $300 \mu \mathrm{Ci}$ of $\mathrm{L}-\left[1-{ }^{14} \mathrm{C}\right]$ leucine/ $\mathrm{kg}$ body wt. was injected into the tail vein $60 \mathrm{~min}$ before death.

Assay of galactosyltransferase activity. The activity of this marker enzyme of the Golgi apparatus is usually measured by a radiochemical assay originally developed by Babad \& Hassid (1966) and later modified by Fleischer et al. (1969). Owing to the timeconsuming chromatography $(50-72 \mathrm{~h})$, this test is not suitable for routine investigations. Therefore a linked-assay system has been developed. Activity is measured spectrophotometrically at $334 \mathrm{~nm}$ and $37^{\circ} \mathrm{C}$ by following the liberation of UDP coupled to nicotinamide nucleotide reduction:

UDP-galactose $+N$-acetylglucosamine

Galactosyltransferase

galactosyl- $N$-acetylglucosamine + UDP

$$
\text { UDP + ATP } \stackrel{\text { Nucleoside diphosphate kinase }}{\longrightarrow} \text { UTP + ADP }
$$

UTP + glucose 1-phosphate

UDP-glucose pyrophosphorylase

$$
\text { UDP-glucose }+\mathbf{P P}_{1}
$$

UDP-glucose $+2 \mathrm{NAD}^{+}+\mathrm{H}_{2} \mathrm{O}$

$$
\stackrel{\text { UDP-glucose dehydrogenase }}{\longrightarrow}
$$

UDP-glucuronate $+2 \mathrm{NADH}+2 \mathrm{H}^{+}$

Kalckar \& Anderson (1957) described an enzymic assay for the determination of UTP, and Keppler et al. (1970b) gave a sequential enzymic assay for the determination of the uracil nucleotides UDP-glucose, UTP, UDP and UMP.

The standard assay mixture in a final vol. of $0.85 \mathrm{ml}$ ( $\mathrm{pH} 7.6)$ contained glycine $(300 \mu \mathrm{mol})$, sodium cacodylate $(120 \mu \mathrm{mol}), \mathrm{NAD}^{+}(1.5 \mu \mathrm{mol})$, ATP $(2 \mu \mathrm{mol})$, glucose 1-phosphate $(1.5 \mu \mathrm{mol}), \mathrm{MnCl}_{2}$ $(40 \mu \mathrm{mol})$, magnesium acetate $(10 \mu \mathrm{mol}), 2$-mercaptoethanol $(10 \mu \mathrm{mol})$, UDP-galactose $(0.5 \mu \mathrm{mol})$, UDPglucose dehydrogenase (0.1 unit), UDP-glucose pyrophosphorylase (2.5 units), nucleoside diphosphate kinase ( 2 units), and approx. $100 \mu$ l of sus- pended Golgi-rich fraction (0.1-0.2 $\mathrm{mg}$ of protein). The reaction was initiated by the addition of $50 \mu \mathrm{mol}$ of $N$-acetyl-D-glucosamine.

The assay does not include a detergent, because it destroys the native membrane structure making it difficult to compare studies in vitro and in vivo. Probably for this reason Wagner \& Cynkin (1971) do not add any detergent when determining the transfer of glucosamine, galactose or $\mathrm{N}$-acetylneuraminic acid to an endogenous protein acceptor. The galactosidase does not influence the determination of galactosyltransferase activity, because the extinction remains constant as long as the galactosyl acceptor $N$-acetyl-D-glucosamine has not been added. The possible influence of galactosidase activity on the new linkage formed was not studied. In control experiments the activity of galactosyltransferase was determined in a radiochemical assay with UDP-D$\left[1-{ }^{14} \mathrm{C}\right]$ galactose as substrate (Fleischer et al., 1969). In liver cells, free $N$-acetyl-D-glucosamine does not occur and is therefore of minor importance as an acceptor for D-galactose. Therefore, where indicated, activity was determined by using an endogenous trichloroacetic acid-precipitable protein of the Golgi-rich fraction as the galactosyl acceptor as described by Wagner \& Cynkin (1969a,b).

Enzymic assays. Published procedures were used to measure the enzymes 5 '-nucleotidase (EC 3.1.3.5) (Michell \& Hawthorne, 1965), glucose 6-phosphatase (EC 3.1.3.9) (de Duve et al., 1955) and succinate-2( $p$-iodophenyl) - 3-( $p$-nitrophenyl) - 5-phenyltetrazolium chloride reductase (Pennington, 1961).

Protein determinations. The protein content of membrane fractions was determined by the method of Lowry et al. (1951). For serum and homogenates the biuret method was preferred (Beisenherz et al., 1953). Before the addition of the biuret reagent protein was precipitated either by $10 \%(\mathrm{w} / \mathrm{v})$ trichloroacetic acid or by dioxan. Crystalline bovine serum albumin was used as a standard.

Determination of radioactivity. Protein-bound radioactivity was determined by the method of Mans \& Novelli (1960) with slight modifications. A sample $(0.1-0.2 \mathrm{ml})$ of the homogenate, Golgi-rich fraction or serum was pipetted on to filter-paper discs (Whatman $3 \mathrm{MM}, 2.3 \mathrm{~cm}$ diam.), which had been mounted on pins. The discs were dried and then transferred to chilled $10 \%(\mathrm{w} / \mathrm{v})$ trichloroacetic acid to precipitate the protein. The discs were left for $60 \mathrm{~min}$ at $4^{\circ} \mathrm{C}$ and then subjected to the following washing procedure to remove free amino acids or non-protein materials: $15 \mathrm{~min}$ at $4^{\circ} \mathrm{C}$ in $5 \%(\mathrm{w} / \mathrm{v})$ trichloroacetic acid, $30 \mathrm{~min}$ at $90^{\circ} \mathrm{C}$ in $5 \%(\mathrm{w} / \mathrm{v})$ trichloroacetic acid, $15 \mathrm{~min}$ at $4^{\circ} \mathrm{C}$ in $5 \%(\mathrm{w} / \mathrm{v})$ trichloroacetic acid, $30 \mathrm{~min}$ at $37^{\circ} \mathrm{C}$ in ether-ethanol $(1: 1, \mathrm{v} / \mathrm{v})$, and finally $15 \mathrm{~min}$ at $22^{\circ} \mathrm{C}$ in ether. However, when galactosyltransferase was assayed by using an endogenous acceptor protein, heating 
was omitted, since under these conditions $10 \%$ of the D-galactose incorporated will be liberated by acid hydrolysis.

Since counting efficiency depends on protein concentration (Schreiber et al., 1971), comparable amounts of protein were always applied to the filter paper discs. Radioactivity was determined by counting the air-dried discs in $10 \mathrm{ml}$ of toluene scintillation mixture (Kallmann et al., 1958) in a Packard liquidscintillation spectrometer. Radiochemically pure rat $\left[{ }^{14} \mathrm{C}\right]$ albumin was used as a standard. Radioactivity was measured until sufficient counts had accumulated to give a counting error of $\pm 5 \%$ after subtraction of background counts.

Sodium dodecylsulphate-polyacrylamide-gelelectrophoresis. A portion $(200 \mu \mathrm{l})$ of suspended Golgi membranes $(220 \mu \mathrm{g}$ of protein) was sedimented in an Eppendorf centrifuge (Netheler and Hinz G.m.b.H., Hamburg, Germany) for $10 \mathrm{~min}$ at $8000 \mathrm{~g}$. Then $200 \mu \mathrm{l}$ of $0.1 \mathrm{M}$-sodium phosphate buffer (pH7.1), $1.7 \mu \mathrm{mol}$ of sodium dodecyl sulphate, and $18 \mu \mathrm{mol}$ of 2-mercaptoethanol were added to the pellet and the mixture was incubated for $3 \mathrm{~min}$ at $100^{\circ} \mathrm{C}$. Half of the sample was transferred to a second Eppendorf tube and to both of them $0.2 \mu \mathrm{mol}$ of Bromophenol Blue and a drop of distilled glycerol were added. The samples were subjected to electrophoresis in a Tris-glycine buffer system, pH8.3 (Tris, $0.012 \mathrm{M}$; glycine, $0.16 \mathrm{M}$; sodium dodecyl sulphate, $0.004 \mathrm{M}$ ) for both upper and lower chambers. The preparation of the polyacrylamide gel with $10 \%(w / v)$ acrylamide in the running gel was described in detail by Glossmann \& Lutz (1970). The current ( $2 \mathrm{~mA} /$ tube) was maintained until the dye marker Bromophenol Blue had reached the lower end of the tube. The gels were stained for $90 \mathrm{~min}$ with Coomassie Brilliant Blue $(0.25 \%)$ in ethan-1-ol-acetic acid $(9: 1, v / v)$ and were destained for $30 \mathrm{~min}$ in methanol-acetic acidwater $(2: 3: 35$, by vol.).
Isolation and determination of albumin. Albumin was liberated from the Golgi vesicles and purified as described by Glaumann \& Ericson (1970). Portions (2-15 $\mu \mathrm{g}$ of protein) of the ethanol extracts were subjected to polyacrylamide-gel electrophoresis with ribonuclease $\mathrm{A}$ as the marker protein. Radiochemically pure rat liver albumin was used for comparison or was added to the samples before electrophoresis. Only one major band was seen with the same relative mobility compared with ribonuclease A as rat liver albumin. To determine the amount of albumin present in the sample, density tracings of the gels were recorded with a Gilford spectrometer equipped with the linear transport accessory (Gilford Instruments, Oberlin, Ohio, U.S.A.), with the following operation procedure: wavelength 550 or $630 \mathrm{~nm}$, aperture plate $0.10 \mathrm{~mm} \times 2.36 \mathrm{~mm}$, filter $410-660 \mathrm{~nm}$, scan rate $1 \mathrm{~cm} / \mathrm{min}$, chart speed $1.27 \mathrm{~cm}(0.5 \mathrm{in}) / \mathrm{min}$. By using various concentrations of standard albumin a calibration curve was established. The maximum extinction value is a more suitable measure for the protein content/band than the area beneath the extinction curve. Up to $10 \mu \mathrm{g}$ of albumin/band, a linear increase in extinction was observed.

The density tracings were recorded, then the gels were sliced and the bands containing radioactively labelled albumin removed and pressed through a sieve (sieve pores $0.2 \mathrm{~mm}$ diam.). The radioactivity was measured in Bray's (1960) scintillation mixture.

\section{Results \\ Secretion of glycoproteins}

The normal 'galactose-time' (see the Materials and Methods section) was between 5 and $6 \mathrm{~min}$. Owing to the injection of D-galactosamine this time was prolonged to between 8 and $10 \mathrm{~min}$ (Fig. 1). Similar results were obtained with $\mathrm{L}-\left[{ }^{3} \mathrm{H}\right]$ fucose. The 'fucosetime' was lengthened from 8 to about 13 min (Fig. 1).
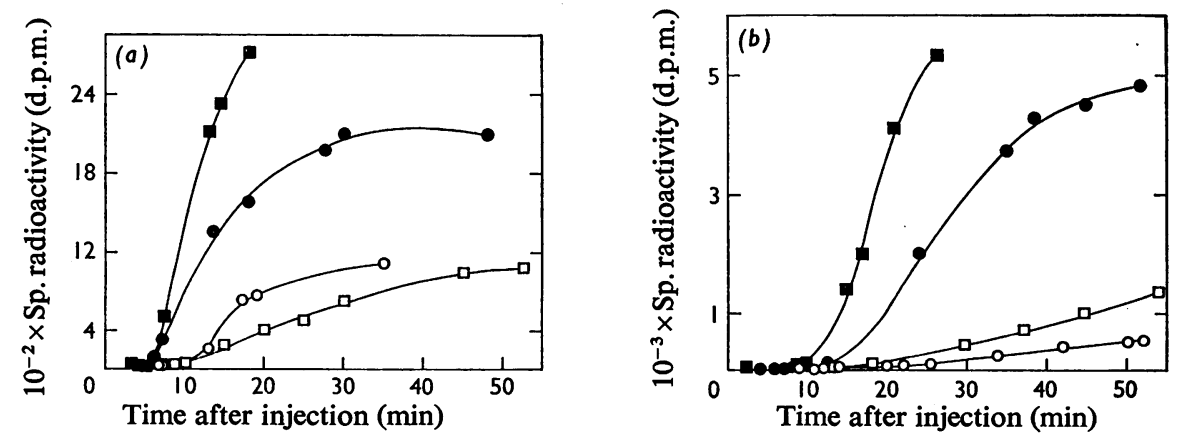

Fig. 1. Specific radioactivity of glycoproteins in the serum of rats

D-Galactosamine was injected at $08.30 \mathrm{~h}$; at $13.30 \mathrm{~h}$ the rats received an intravenous injection of $100 \mu \mathrm{Ci}$ of D-[1- $\left.{ }^{14} \mathrm{C}\right]$ galactose $(a)$ or L-[ $\left[{ }^{3} \mathrm{H}\right]$ fucose $(b) / \mathbf{k g}$ body wt. $\bullet, \mathbf{m}$, Sp. radioactivity of control animals; $\bigcirc, \square$, Sp. radioactivity after D-galactosamine administration. 


\section{Table 1. Activities of marker enzymes of the homogenate and the Golgi-rich fraction}

D-Galactosamine hydrochloride $(375 \mathrm{mg} / \mathrm{kg}$ body wt.) was injected intraperitoneally. The injections were given at $08: 30 \mathrm{~h}$, and the animals were killed either at $14: 30 \mathrm{~h}$ or $20: 30 \mathrm{~h}$. Units of specific activity are given as $\mu \mathrm{mol}$ of $P_{1}$ released/h per mg of protein, except for succinate-2-(p-iodophenyl)-3-( $p$-nitrophenyl)-5-phenyltetrazolium chloride reductase which is given as $\mu \mathrm{mol}$ of 2-( $p$-iodophenyl)-3-( $p$-nitrophenyl)-5-phenyltetrazolium chloride reduced/h per $\mathrm{mg}$ of protein. All enzymes were assayed at $37^{\circ} \mathrm{C}$. Values are means from ten determinations \pm S.D.

Specific activity

( $\mu \mathrm{mol} / \mathrm{h}$ per $\mathrm{mg}$ of protein)

\begin{tabular}{|c|c|c|c|c|}
\hline Enzyme & Cell fraction & Control & $\begin{array}{l}\text { D-galac- } \\
\text { tosamine }\end{array}$ & $\begin{array}{l}\text { D-galac- } \\
\text { tosamine }\end{array}$ \\
\hline $5^{\prime}$-Nucleotidase & $\begin{array}{l}\text { Homogenate } \\
\text { Golgi-rich }\end{array}$ & $\begin{array}{l}3.9 \pm 0.6 \\
3.6 \pm 0.4\end{array}$ & $\begin{array}{l}3.5 \pm 0.5 \\
3.6 \pm 0.3\end{array}$ & $\begin{array}{l}3.1 \pm 0.6 \\
3.4 \pm 0.6\end{array}$ \\
\hline Glucose 6-phosphatase & $\begin{array}{l}\text { Homogenate } \\
\text { Golgi-rich }\end{array}$ & $\begin{array}{l}4.3 \pm 0.9 \\
4.5 \pm 1.1\end{array}$ & $\begin{array}{l}5.2 \pm 0.6 \\
6.2 \pm 1.0\end{array}$ & $\begin{array}{l}5.0 \pm 0.6 \\
6.3 \pm 0.6\end{array}$ \\
\hline $\begin{array}{l}\text { Succinate-2-( } p \text {-iodophenyl)-3-(p-nitrophenyl)-5- } \\
\text { phenyltetrazolium chloride reductase }\end{array}$ & $\begin{array}{l}\text { Homogenate } \\
\text { Golgi-rich }\end{array}$ & $\begin{array}{l}0.74 \pm 0.11 \\
0.04 \pm 0.01\end{array}$ & $\begin{array}{l}0.85 \pm 0.10 \\
0.05 \pm 0.01\end{array}$ & $\begin{array}{l}0.80 \pm 0.10 \\
0.07 \pm 0.02\end{array}$ \\
\hline
\end{tabular}

Table 2. Specific activity of UDP-galactose- $N$-acetyl-Dglucosamine galactosyltransferase

For comparison, the activity of the transferase was determined in a radiochemical assay. The incubation mixture of galactosyltransferase contained $6 \mu \mathrm{mol}$ of sodium cacodylate buffer (pH6.75), $4 \mu \mathrm{mol}$ of $\mathrm{MnCl}_{2}, 1 \mu \mathrm{mol}$ of $\mathrm{MgCl}_{2}, 3 \mu \mathrm{mol}$ of 2-mercaptoethanol, $0.15 \mu \mathrm{mol}$ of UDP- $\left[{ }^{14} \mathrm{C}\right]$ galactose and $50 \mu \mathrm{l}$ of Golgi-rich fraction (50-150 $\mu \mathrm{g}$ of protein), in a total volume of $0.1 \mathrm{ml}$. The reaction was started by the addition of $4 \mu \mathrm{mol}$ of $N$-acetylD-glucosamine. Incubation was carried out for 30 or $60 \mathrm{~min}$ at $37^{\circ} \mathrm{C}$. Blank incubation mixtures contained no $\mathrm{N}$-acetyl-D-glucosamine. The incubation was terminated by addition of $12 \mu \mathrm{mol}$ of EDTA (pH 7.4) and heating for $60 \mathrm{~s}$ at $90^{\circ} \mathrm{C}$, then the entire reâction mixtures were applied to Whatman DE-81 paper and chromatographed for 48-72h with butan-1-ol-propan-1-ol-water $(3: 1: 1$, by vol.). The amount of radioactivity was determined by counting successively 0.5 or $1.0 \mathrm{~cm}$-wide strips in $10 \mathrm{ml}$ of toluene scintillation mixture (Kallmann et al., 1958). The unit of specific activity is expressed in nmol of D-galactose transferred/h per $\mathrm{mg}$ of protein at $37^{\circ} \mathrm{C}$. Values are means \pm S.D. from five determinations.

Specific
activity
nmol/h per $\mathrm{mg}$
of protein)

Homogenate

Cell fraction of protein)

Supernatant after the first centrifugation

Membrane fraction after the second

$2.6 \pm 0.3$

$8.0 \pm 1.5$

$52.0 \pm 4.3$

centrifugation

Golgi-rich fraction after density-gradient $\quad 310.0 \pm 20$ centrifugation

Moreover, the amount of secreted glycoprotein was markedly decreased, as shown by measurements of the specific radioactivity of serum glycoproteins.

\section{Purity of the Golgi-rich fraction}

The purity of the Golgi-rich fraction was checked by both morphological (Plate 1) and biochemical criteria. In comparison with data from the literature (Morré et al., 1969; Leelavathi et al., 1970; Fleischer Fleischer, 1970), the preparations were contaminated to a lesser extent by plasma membranes but showed a slightly higher content of fragments from the endoplasmic reticulum. The specific activity of $5^{\prime}-$ nucleotidase, as a marker enzyme for plasma membranes, was only approx. $5 \%$ of that of enriched plasma-membrane fractions (Reutter \& Bachmann, 1971). The contamination by mitochondria was negligible (Table 1), as shown by measuring succinate-2-( $p$-iodophenyl)-3-( $p$-nitrophenyl)-5-phenyltetrazolium chloride reductase activity as a sensitive marker enzyme for mitochondria (Pennington, 1961). The best-known marker enzyme of the Golgi apparatus is UDP-galactose- $N$-acetyl-D-glucosamine galactosyltransferase (Morré et al., 1969; Fleischer et al., 1969). This enzyme was enriched 100-120fold relative to the homogenate (Table 2). Injection of D-galactosamine hydrochloride had no significant influence on the purity of the Golgi-rich fraction, as shown by the specific enzyme activities (Table 1).

\section{Characteristics of liver galactosyltransferase}

pH optimum. Fig. 2 shows the effect of $\mathrm{pH}$ on the transfer of D-galactose from UDP-galactose to the exogenous acceptor $N$-acetyl-D-glucosamine. A broad pH optimum was found between pH7.4 and 8.2. In glycine-cacodylate buffer maximum activity occurred at about pH 7.5.

Protein- and time-dependency. Fig. 3 shows that the enzyme activity directly depends on protein content, i.e. the transfer of D-galactose increases with 
the amount of Golgi-rich fraction added. A similar correlation was measured in investigations of timedependency. After initiation of the reaction by addition of $\mathrm{N}$-acetyl-D-glucosamine the progress curve showed a short lag period for about $4 \mathrm{~min}$ and was then linear with time up to $30 \mathrm{~min}$.

Effects of substrate and acceptor concentrations. The effect of UDP-galactose and $N$-acetyl-Dglucosamine on transferase activity was determined.

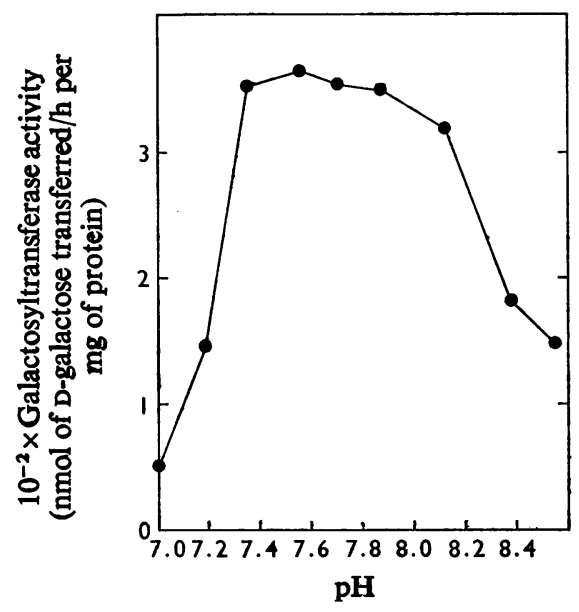

Fig. 2. Effect of $p H$ on UDP-galactose-N-acetyl-Dglucosamine galactosyltransferase

Activity was measured spectrophotometrically at $334 \mathrm{~nm}$ and $37^{\circ} \mathrm{C}$ by following the liberation of UDP coupled to nicotinamide nucleotide reduction. Assays were carried out as described in the Materials and Methods section.
When the data were plotted by the method of Lineweaver \& Burk (1934), straight lines were observed (Fig. 4). The Michaelis constants $\left(K_{m}\right)$ are calculated to be $0.11 \mathrm{~mm}$ for UDP-galactose with $N$-acetyl-D-glucosamine as exogenous acceptor, and $19 \mathrm{~mm}$ for $N$-acetyl-D-glucosamine itself. These values agree well with the data from radiochemical assays (Spiro \& Spiro, 1968; Wagner \& Cynkin, 1971). For comparison the $K_{m}$ value was determined by using

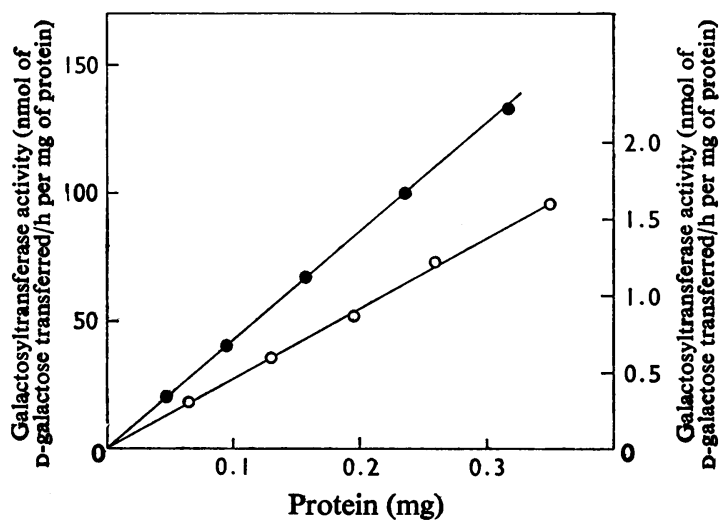

Fig. 3. Protein-dependency of the transfer of $\mathrm{D}$-galactose to an exogenous and endogenous acceptor

The transfer of D-galactose to the exogenous acceptor $N$-acetyl-D-glucosamine was measured spectrophotometrically (left ordinate, $\ominus$ ), whereas the transfer of $\mathrm{D}-\left[{ }^{14} \mathrm{C}\right]$ galactose to the endogenous protein acceptor of the Golgi-rich fraction was determined in a radiochemical assay (right ordinate, $O$ ). For other details, see the legend to Table 2 and the Materials and Methods section.
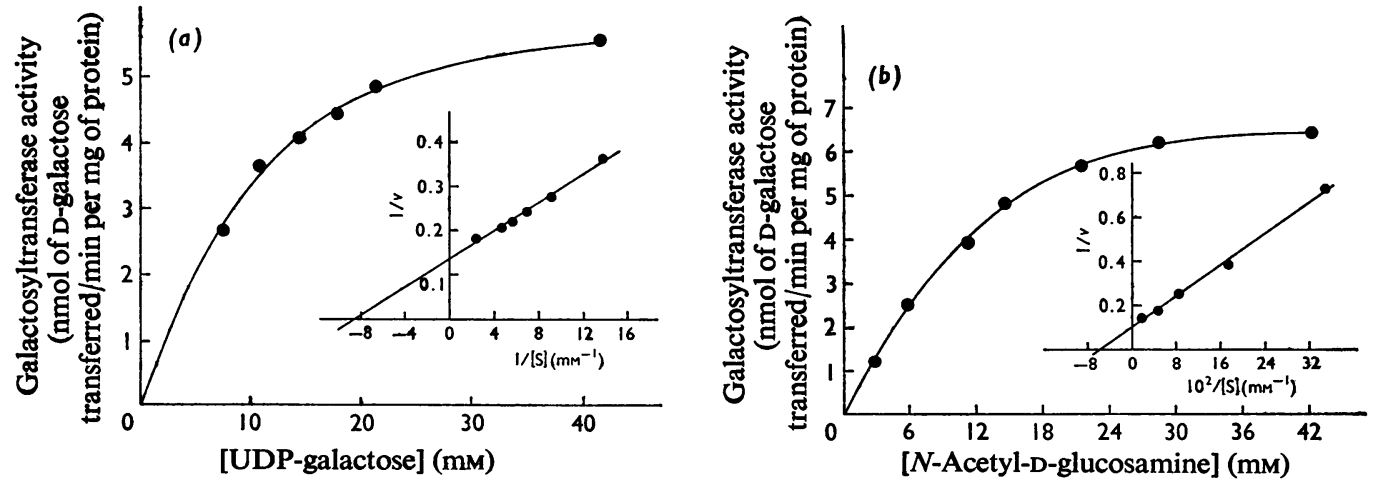

Fig. 4. Determination of the $K_{m}$ values of the UDP-galactose-N-acetyl-D-glucosamine galactosyltransferase

The standard incubation mixture as described in the Materials and Methods section was used except that either the substrate UDP-galactose ( $a$ ) or the acceptor $N$-acetyl-D-glucosamine $(b)$ was added at different concentrations to the reaction mixture. The regression equations of the Linweaver-Burk plots were calculated and are shown as insets. 


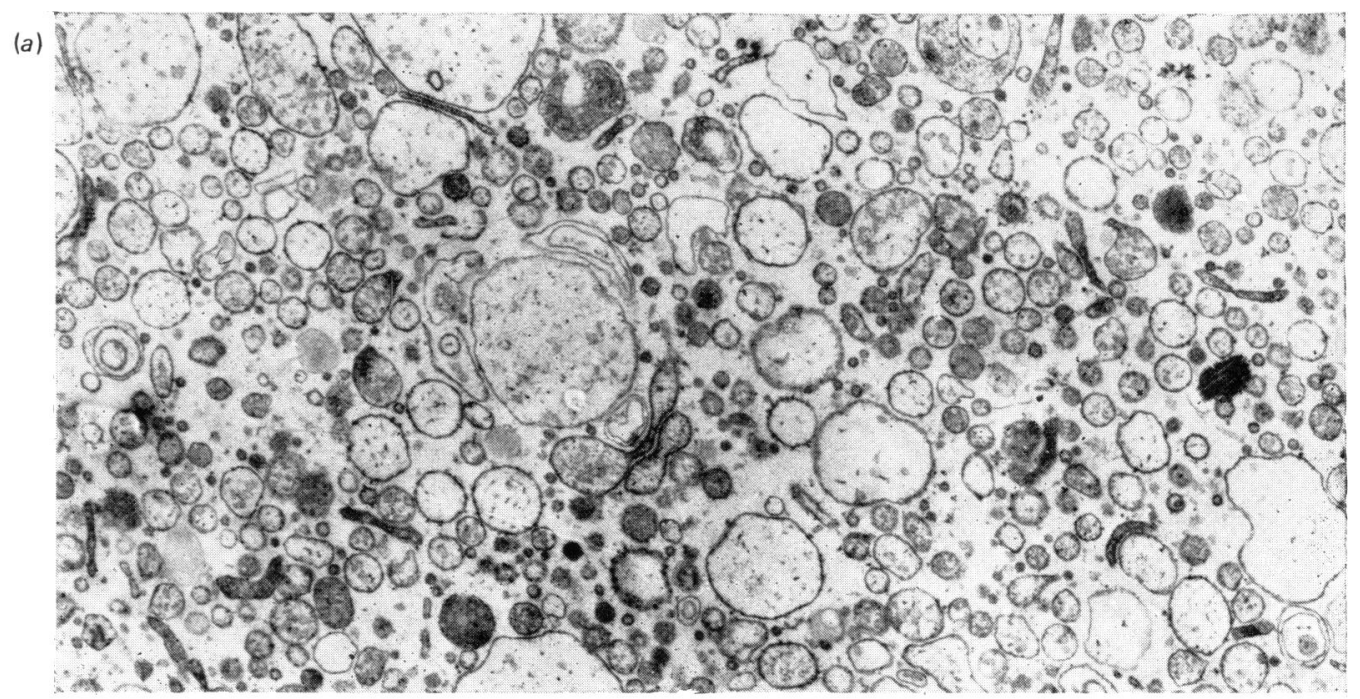

(b)

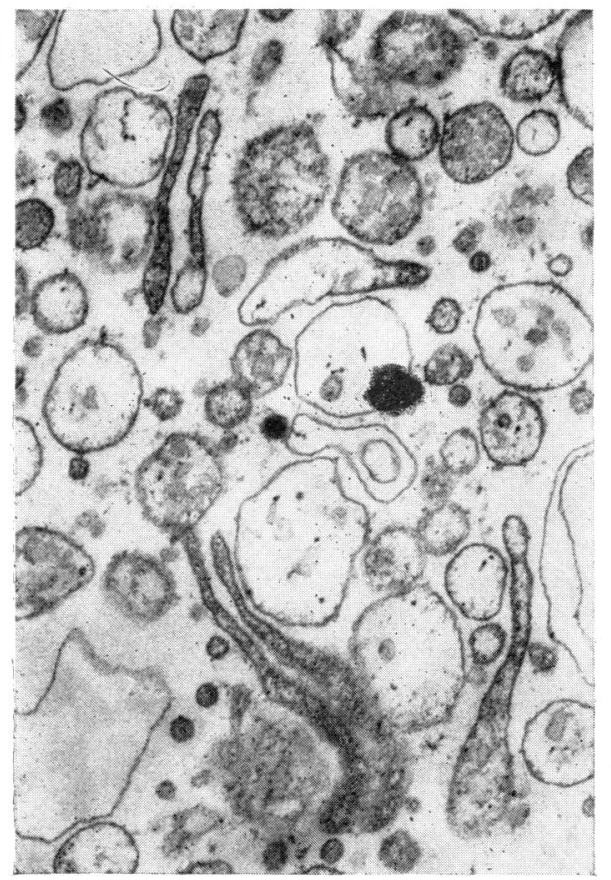

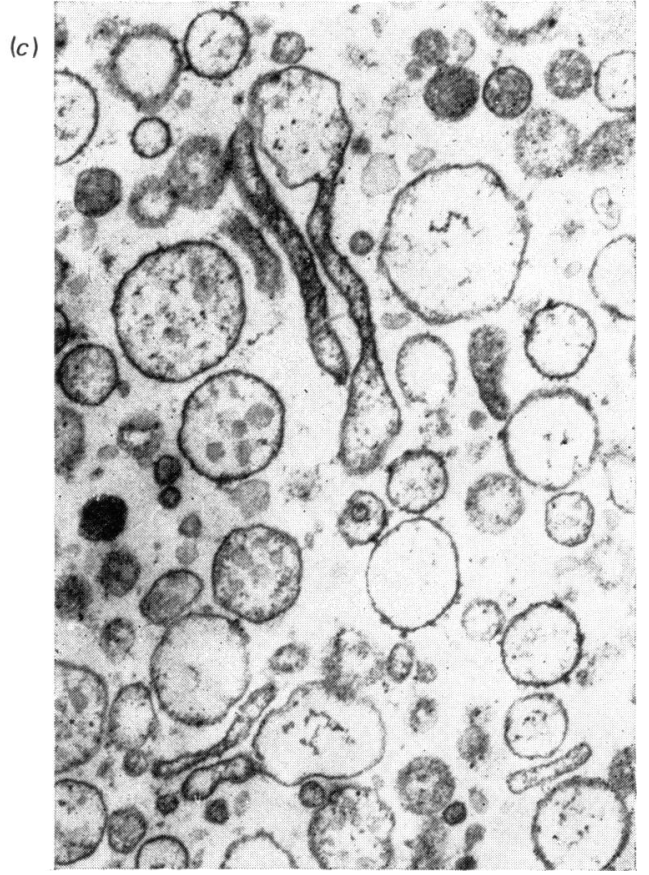

EXPLANATION OF PLATE I

Electron micrographs of Golgi-rich fractions isolated by discontinuous gradient centrifugation

(a) Micrograph shows that the fraction consists mainly of very-low-density-lipoprotein-loaded Golgi elements (magnification $\times 25000)$. $(b)$ and $(c)$ Characteristic features of Golgi cisternae with associated vesicles (magnification $\times 50000)$. 

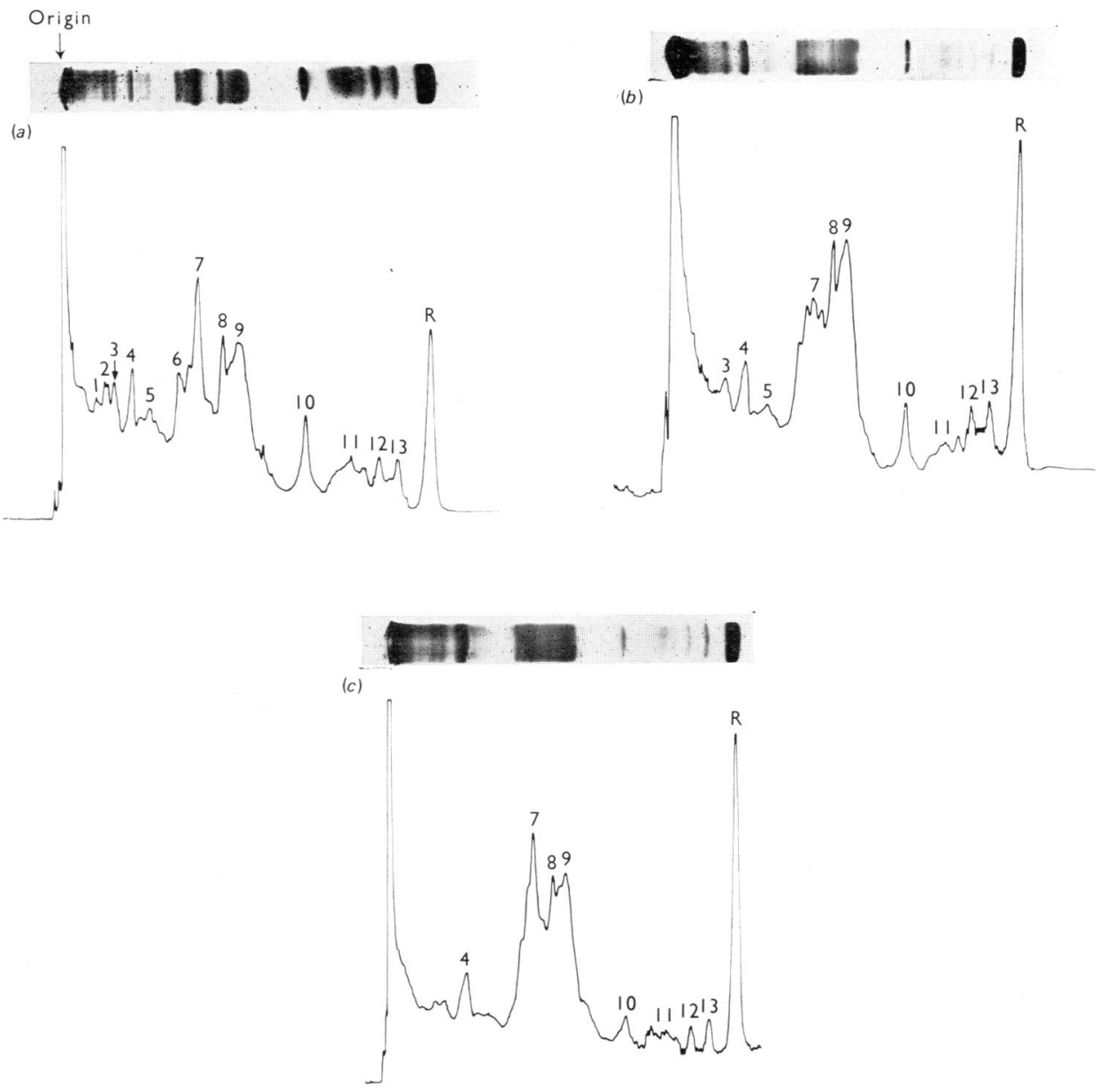

\section{EXPLANATION OF PLATE 2}

Electrophoretic comparison of Golgi-rich fractions at different times after D-galactosamine administration

The Golgi apparatus was enriched 100-120-fold relative to the homogenate. Experimental details are given in the Materials and Methods section. (a) Control animals, $(b) 6 \mathrm{~h}$ after D-galactosamine injection, $(c) 12 \mathrm{~h}$ after D-galactosamine injection. The running gel contained $10 \%(\mathrm{w} / \mathrm{v})$ acrylamide. All gels were stained with Coomassie Brilliant Blue, destained and analysed on a Gilford spectrophotometer equipped with a gel-scanning device. The numbers 1-13 indicate the main protein bands. The band marked with ' $R$ ' represents ribonuclease $A$, which was added to the samples before electrophoresis. 
Table 3. Transfer of $\mathrm{D}-\left[1-{ }^{14} \mathrm{C}\right]$ gatactosamine from UDP$\left[1-{ }^{14} \mathrm{C}\right]$ galactosamine to an endogenous protein acceptor

The incubation mixture was similar to the assay system described for Table 2. UDP- $\left[{ }^{14} \mathrm{C}\right]$ galactose was replaced by UDP- $\left[1-{ }^{14} \mathrm{C}\right]$ galactosamine and the exogenous acceptor $\mathrm{N}$-acetyl-D-glucosamine was replaced by the endogenous protein acceptor present in the Golgi-rich fraction as described by Wagner \& Cynkin $(1969 a, b)$. The reaction was initiated by addition of the substrate UDP- $\left[1{ }^{14} \mathrm{C}\right]$ galactosamine. Incubation was carried out for $5 \mathrm{~min}$ at $37^{\circ} \mathrm{C}$. Protein-bound radioactivity was determined as described by Mans \& Novelli (1960). For further experimental details, see the legend to Table 2 and the Materials and Methods section.

$\begin{array}{cc}\begin{array}{c}\text { Concentration of UDP- } \\ {\left[11^{14} \text { Clgalactosamine in }\right.} \\ \text { the assay system } \\ \text { (nmol/ml) }\end{array} & \begin{array}{c}\text { Transfer of } D-\left[1-{ }^{14} \mathrm{C}\right]- \\ \text { galactosamine to an } \\ \text { endogenous protein acceptor } \\ \text { (nmol/h per mg of protein) }\end{array} \\ 13.4 & 0.13 \\ 26.8 & 0.20 \\ 40.2 & 0.24 \\ 53.6 & 0.28 \\ 134.0 & 0.36\end{array}$

the endogenous acceptor protein of the Golgi-rich fraction. Under these conditions the Michaelis constant was calculated to be $11 \mu \mathrm{M}$ for UDPgalactose.

\section{Substrate specificity}

Since UDP-galactosamine only occurs in significant amounts after administration of D-galactosamine hydrochloride (Keppler et al., 1970c; Bauer \& Reutter, 1973), it was decided to study whether this compound can be used by the galactosyltransferase instead of UDP-galactose. In order to simulate the situation found in the living cell the enzyme activity was determined by using an endogenous trichloroacetic acid-precipitable protein of the Golgi-rich fraction as glycosyl acceptor as described by Wagner \& Cynkin $(1959 a, b)$. Incorporation of radioactivity from UDP-[1-14 C]galactosamine into the acceptor did indeed occur (Table 3). Under optimum conditions the amount incorporated reached $9 \%$ of that with D-galactose (see Table 4).

\section{Inhibition of galactosyltransferase by UDP-galactos- amine and galactosamine 1-phosphate}

The transfer of $\left[{ }^{14} \mathrm{C}\right]$ galactose from UDP- $\left[{ }^{14} \mathrm{C}\right]-$ galactose to an endogenous acceptor protein of the Golgi-rich fraction is inhibited by galactosamine metabolites. The $K_{\mathrm{i}}$ value is calculated to be $1.4 \mathrm{~mm}$ for UDP-galactosamine. Galactosamine 1-phosphate is only effective at higher concentrations. Halfmaximal inhibition is reached at $10 \mathrm{~mm}$-galactosamine 1-phosphate.
Table 4. Thansfer of $\mathrm{D}-\left[{ }^{14} \mathrm{C}\right]$ galactose from UDP-D- $\left[{ }^{14} \mathrm{C}\right]-$ galactose to an endogenous and exogenous acceptor

D-Galactosamine hydrochloride ( $375 \mathrm{mg} / \mathrm{kg}$ body wt.) was injected intraperitoneally. Units of specific activity are expressed in $\mathrm{nmol}$ of $\mathrm{D}$-galactose transferred/h per $\mathrm{mg}$ of protein at $37^{\circ} \mathrm{C}, \pm$ S.D. from eight measurements. For experimental details, see the legend to Table 2 and the Materials and Methods section.

\begin{tabular}{|c|c|c|c|}
\hline \multirow[b]{2}{*}{ Type of acceptor } & \multicolumn{3}{|c|}{$\begin{array}{l}\text { Sp. activity (nmol/h per mg of } \\
\text { protein) }\end{array}$} \\
\hline & Control & $\begin{array}{l}\text { At } 3 \mathrm{~h} \text { after } \\
\text { D-galac- } \\
\text { tosamine }\end{array}$ & $\begin{array}{l}\text { At } 6 \mathrm{~h} \text { after } \\
\text { D-galac- } \\
\text { tosamine }\end{array}$ \\
\hline $\begin{array}{l}\text { Endogenous protein } \\
\text { acceptor }\end{array}$ & $4.9 \pm 0.1$ & $4.1 \pm 0.05$ & $2.9 \pm 0.2$ \\
\hline $\begin{array}{l}\text { Exogenous acceptor } \\
N \text {-acetyl-D-glucos- } \\
\text { amine }\end{array}$ & $300 \pm 15$ & $292 \pm 10$ & $295 \pm 12$ \\
\hline
\end{tabular}

Diminution of endogenous protein acceptor concentration

At 3 and $6 \mathrm{~h}$ after the administration of D-galactosamine, the activity of the galactosyltransferase was determined with both endogenous and exogenous acceptors. From the data (Table 4) it can be concluded that the activity of the transferase was not altered. Nevertheless the incorporation of D-galactose into the endogenous protein acceptor was decreased to $60 \%$ of the control value. We assume that this decrease is due to a fall in the acceptor protein concentration in the Golgi apparatus after D-galactosamine administration.

\section{Inhibition of incorporation of $\mathrm{L}-\left[1-{ }^{14} \mathrm{C}\right]$ leucine}

At different times after D-galactosamine injection the rats received a single dose of $100 \mu \mathrm{Ci}$ of $\mathrm{L}-\left[1-{ }^{14} \mathrm{C}\right]$ leucine $/ \mathrm{kg}$ body wt. The animals were killed $1 \mathrm{~h}$ later and the protein-bound radioactivity was determined in serum, homogenate and Golgi-rich fraction (Table 5). Already $3 \mathrm{~h}$ after the administration of the amino sugar an appreciable decrease in $\mathrm{L}-\left[1{ }^{14} \mathrm{C}\right]$ leucine incorporation was observed. The pool of free $\mathrm{L}$-leucine has not been altered at this time (Reutter, 1971). At the same time a diminution of serum protein content was found.

Minimum incorporation was measured $6 \mathrm{~h}$ after the administration of D-galactosamine. The Golgirich fraction contained only $40 \%$ of the radioactivity compared with controls. Determinations of radioactivity in homogenate and serum show a similar time-course of inhibition of $\mathrm{L}-\left[1-{ }^{14} \mathrm{C}\right]$ leucine incorporation. To study the influence of a diminished uridylate concentration on protein synthesis, Dgalactosamine together with uridine was given to 
Table 5. Effect of $\mathrm{D}$-galactosamine on the incorporation of $\mathrm{L}-\left[1-{ }^{14} \mathrm{C}\right]$ leucine

The specific radioactivity was determined as a function of time after a single injection of $375 \mathrm{mg}$ of D-galactosamine hydrochloride/ $\mathrm{kg}$ body wt. At $1 \mathrm{~h}$ before death $100 \mu \mathrm{Ci}$ of $\mathrm{L}-\left[1-{ }^{14} \mathrm{C}\right] l e u c i n e / \mathrm{kg}$ body wt. was given via the tail vein. Protein-bound radioactivity was determined as described in the Materials and Methods section. Values are means \pm S.D. from five determinations.

Sp. radioactivity (d.p.m./mg of protein)

\begin{tabular}{lcccc}
\cline { 2 - 4 } \multicolumn{1}{c}{ Cell fraction } & Control & $\begin{array}{c}\text { At } 3 \mathrm{~h} \text { after } \\
\text { D-galactosamine }\end{array}$ & $\begin{array}{c}\text { At } 6 \mathrm{~h} \text { after } \\
\text { D-galactosamine }\end{array}$ & $\begin{array}{c}\text { At } 12 \mathrm{~h} \text { after } \\
\text { D-galactosamine }\end{array}$ \\
Serum & $2240 \pm 150$ & $1400 \pm 240$ & $790 \pm 150$ & $940 \pm 80$ \\
Homogenate & $2240 \pm 320$ & $1650 \pm 160$ & $1280 \pm 130$ & $1760 \pm 80$ \\
Golgi-rich fraction & $15020 \pm 1050$ & $9450 \pm 510$ & $7250 \pm 570$ & $11460 \pm 230$
\end{tabular}

Table 6. Relationship between the incorporation of $\mathrm{L}-\left[1-{ }^{14} \mathrm{C}\right]$ leucine and the concentration of uracil nucleotides after the administration of $\mathrm{D}$-galactosamine

The dose of uridine used was $1.2 \mathrm{~g} / \mathrm{kg}$ body wt. All injections were given intravenously. The first dose was given together with $375 \mathrm{mg}$ of D-galactosamine hydrochloride $/ \mathrm{kg}$ body wt. at $08.30 \mathrm{~h}$. In cases where several doses of uridine were administered, they were injected at time-intervals of $2 \mathrm{~h}$. At $13: 30 \mathrm{~h}$ the rats received a single injection of $100 \mu \mathrm{Ci}$ of $\mathrm{L}-\left[1-{ }^{14} \mathrm{C}\right] \mathrm{leucine} / \mathrm{kg}$ body wt. via the tail vein; the rats were killed at $14: 30 \mathrm{~h}$. Values are means \pm S.D. from five measurements.

Incorporation of $\mathrm{L}-\left[1{ }^{14} \mathrm{C}\right]$ leucine (d.p.m./mg of protein)

No. of doses of uridine $(1.2 \mathrm{~g} / \mathrm{kg})$
injected

One

Two

Three

Controls:

(a) Uridine alone

(b) D-Galactosamine alone

(c) Untreated animals

Serum
$1580 \pm 100$
$1870 \pm 270$
$1960 \pm 180$

$2650 \pm 190$

$2300 \pm 140$
Concentration of uracil nucleotides ( $\mathrm{nmol} / \mathrm{g}$ wet wt. of liver)

$\begin{array}{lcc}\text { UTP+UDP } & \begin{array}{c}\text { UDP- } \\ \text { glucose }\end{array} & \begin{array}{c}\text { UDP- } \\ \text { galactose }\end{array} \\ 255 \pm 41 & 149 \pm 11 & 74 \pm 3 \\ 689 \pm 140 & 282 \pm 17 & 86 \pm 25 \\ 820 \pm 132 & 329 \pm 29 & 85 \pm 7\end{array}$

$\begin{array}{ccc}78 \pm 12 & 40 \pm 3 & 27 \pm 5 \\ 310 \pm 14 & 355 \pm 31 & 88 \pm 5\end{array}$

fill up this nucleotide pool (Keppler, 1973; Decker et al., 1973).

After three injections of $1.2 \mathrm{~g}$ of uridine $/ \mathrm{kg}$ body wt. at $2 \mathrm{~h}$ intervals all uridylates were at least in the normal range at the time when $\mathrm{L}-\left[1-{ }^{14} \mathrm{C}\right]$ leucine was given (Table 6). A single injection of uridine together with D-galactosamine led to a decrease in the specific radioactivity to only $70 \%$ of normal values; without uridine administration the specific radioactivity fell to $40 \%$. Even after three injections of uridine the incorporation of $\mathrm{L}-\left[1-{ }^{14} \mathrm{C}\right]$ leucine does not reach normal values again.

The administration of uridine alone to control rats induced a slight stimulation (10-15\%) of the incorporation of $\mathrm{L}-\left[1-{ }^{14} \mathrm{C}\right]$ leucine.

\section{Polyacrylamide-gel electrophoresis}

At $6 \mathrm{~h}$ after D-galactosamine administration the disc electrophoresis patterns and the densitometer tracings of Golgi-rich fractions show a decrease or even a disappearance of various protein bands (Plate 2). This is especially characteristic of band (7) (relative mobility 0.63 compared with ribonuclease $\mathrm{A}$ ).
As judged from the migration behaviour and solubility in trichloroacetic acid and ethanol this band represents albumin. Therefore the albumin content of the Golgi-rich fraction was determined (see the Materials and Methods section). The results confirm the findings of the electrophoretic analysis. At $6 \mathrm{~h}$ after D-galactosamine administration the albumin content was diminished by $45 \%$ compared with untreated rats. Further, the incorporation of $\mathrm{L}$ $\left[1-{ }^{14} \mathrm{C}\right]$ leucine into albumin was decreased by $30 \%$ compared with control animals. From $6 \mathrm{~h}$ after Dgalactosamine administration onwards the protein content increased again, although at $12 \mathrm{~h}$ normal values had not yet been reached. Protein patterns of the gels revealed that minor bands were still missing.

\section{Discussion}

The methods described allow studies on the secretion of glycoproteins and on the function and composition of the Golgi apparatus of rat liver. The purity of the Golgi-rich fraction is indicated by electron-microscopic and biochemical data. 
According to Eylar (1965) glycosylation facilitates the secretion of proteins. With regard to this concept the enzyme galactosyltransferase, which attaches the galactose molecule to the nascent glycoprotein, may play an essential role in the secretion of glycoproteins. Therefore it has been studied more thoroughly during galactosamine hepatitis, which leads to an altered secretion of plasma proteins.

With $N$-acetyl-D-glucosamine as an exogenous acceptor, the transferase activity itself does not change after D-galactosamine injection, whereas the transfer of D-galactose to an endogenous acceptor protein of the Golgi-rich fraction falls to $60 \%$ of the normal value (Table 4). From these results it is concluded that it is the endogenous acceptor protein concentration of D-galactosamine-treated livers that has been diminished.

Owing to the administration of D-galactosamine the substrate of the galactosyltransferase, UDPgalactose, decreases from $88 \pm 12$ to $25 \pm 5 \mathrm{nmol} / \mathrm{g}$ wet wt. of liver (Table 6). In vitro, with an endogenous acceptor protein, the Michaelis constant $\left(K_{m}\right)$ is calculated to be $11 \mu \mathrm{M}$ for UDP-galactose. Consequently the decrease in the substrate concentration caused by D-galactosamine injection should only be of limited influence on transferase activity.

It is noteworthy that the physiological substrate UDP-galactose can partially be replaced by the normally non-occurring UDP-galactosamine, which accumulates in the liver after D-galactosamine administration. Under conditions in vitro the rate of D-galactosamine transfer reaches $9 \%$ of that with D-galactose. It should be recognized that in vivo, under the conditions of galactosamine hepatitis, the concentration of UDP-galactosamine is 20 to 25 times higher than that of UDP-galactose. In glycoproteins, however, even a small amount of Dgalactosamine instead of D-galactose may cause substantial alterations in their specificity and their behaviour, because a sugar with a non-acetylated amino group has been introduced.

According to the endomembrane concept (Morré et al., 1971), the Golgi apparatus is the source of vesicles capable of fusing with the plasma membrane. By this route a non-acetylated D-galactosamine can become part of this subcellular structure. Reutter \& Bachmann (1971) showed that the plasma membrane alters during induction of galactosamine hepatitis.

The measurements presented have shown that D-galactosamine caused a decrease of protein and glycoprotein synthesis as well as a lengthening of the time of secretion for galactose- and fucose-containing glycoproteins. Two reasons may be considered responsible, first, an inhibition of protein synthesis, and secondly, an inhibition of the secretion process itself. The decrease of the albumin content in the Golgi-rich fraction and the measurements of the total protein content in serum and homogenate show a marked decrease in protein synthesis. Moreover, the diminished rate of $\mathrm{L}-\left[1{ }^{14} \mathrm{C}\right]$ leucine incorporation and the lowered content of endogenous protein acceptor for the galactosyltransferase further support the finding of disturbed protein synthesis. The decreased rate of protein synthesis is mostly due to a trapping of uracil nucleotides after the injection of D-galactosamine. The pool of UTP+UDP has been lowered below a value that is no longer sufficient to provide enough substrate for a rapidly-turningover mRNA. Studies on rat liver tyrosine aminotransferase show that a defined concentration of UTP+UDP is needed for the corticosteroid-mediated induction of this enzyme (Reynolds \& Reutter, 1973).

The present paper shows that protein synthesis can be restored to $80 \%$ of normal values, if uridine is injected repeatedly. Similar results have been published by Shinozuka et al. (1973). Therefore, apart from the trapping of uracil nucleotides, a different mechanism must be responsible for the inhibition of the synthesis of several proteins. Previous investigations have shown that galactosamine 1-phosphate and UDP-galactosamine inhibit UDP-glucose pyrophosphorylase (Keppler \& Decker, 1969) and UDPglucose dehydrogenase (Bauer \& Reutter, 1973), and therefore it seems conceivable that some galactosamine metabolites may influence an enzymic step involved in protein synthesis. Shinozuka et al. (1973) speculate that the UDP-hexosamines may be responsible for the formation of ribosomal aggregates.

From the present data, it can be concluded that the disturbed secretion of proteins and glycoproteins of rat liver is due to a cumulative effect: $(a)$ inhibition of protein synthesis leading to a diminution of the endogenous acceptor pool of the galactosyltransferase, (b) inhibition of the galactosyltransferase activity by galactosamine metabolites and $(c)$ replacement of UDP-galactose by UDP-galactosamine.

This work was supported by the Deutsche Forschungsgemeinschaft (Forschergruppe Leber), Bad Godesberg, Germany. We are grateful to Professor K. Decker for valuable discussion. We are greatly indebted to Dr. J. Kartenbeck, Institut für Zellbiologie der Universität Freiberg, for the electron micrographs.

\section{References}

Babad, H. \& Hassid, W. Z. (1966) Methods Enzymol. 8, 346-351

Bauer, Ch. \& Reutter, W. (1973) Biochim. Biophys. Acta 293, 11-14

Bauer, Ch Bachmann, W. \& Reutter, W. (1972) HoppeSeyler's Z. Physiol. Chem. 353, 1053-1058

Beisenherz, G., Boltze, H. J., Bücher, Th., Czok, R., Garbade, K. H., Meyer-Arendt, E. \& Pfleiderer, G. (1953) Z. Naturforsch. B 8, 555-577

Vol. 142 
Bray, A. G. (1960) Anal. Biochem. 1, 279-285

Caccam, J. F., Jackson, J. J. \& Eylar, E. H. (1969) Biochem. Biophys. Res. Commun. 35, 505-511

Caro, L. G. \& Palade, G. E. (1964) J. Cell Biol. 20, 473495

Decker, K., Keppler, D. \& Pausch, J. (1973) Advan. Enzyme Regul. 11, 205-230

de Duve, C., Pressman, B. C., Gianetto, R., Wattiaux, R. \& Applemans, F. (1955) Biochem. J. 60, 604-617

Eylar, E. H. (1965) J. Theor. Biol. 10, 89-113

Fleischer, B. \& Fleischer, S. (1970) Biochim. Biophys. Acta 219, 301-319

Fleischer, B., Fleischer, S. \& Ozawa, H. (1969) J. Cell Biol. 43, 59-79

Glaumann, H. \& Ericson, J. E. (1970) J. Cell Biol. 47, 555-567

Glossmann, H. \& Lutz, F. (1970) Hoppe-Seyler's Z. Physiol. Chem. 351, 1583-1585

Haddad, A., Smith, M. D., Herscovics, A., Nadler, N. J. \& Leblond, C. P. (1971) J. Cell Biol. 49, 856-877

Hagopian, A., Bosmann, D. B. \& Eylar, E. H. (1968) Arch. Biochem. Biophys. 128, 387-396

Hudgin, R. L., Murray, R. K., Pinteric, L., Morris, H. P. \& Schachter, H. (1971) Can. J. Biochem. 49, 61-70

Kalckar, H. M. \& Anderson, E. P. (1957) Methods Enzymol. 3, 976-977

Kallmann, H., Hayes, F. N. \& Furst, M. (1958) in LiquidScintillation Counting (Bell, C. G. \& Hayes, F. N., eds.), p. 56, Pergamon Press, New York

Keppler, D. (1973) Ann. Gastroentérol. 9, 211-221

Keppler, D. \& Decker, K. (1969) Eur. J. Biochem. 10, 219-225

Keppler, D., Lesch, R., Reutter, W. \& Decker, K. (1968) Exp. Mol. Pathol. 9, 279-290

Keppler, D., Rudigier, J., Bischoff, E. \& Decker, K. (1970a) Eur. J. Biochem. 17, 246-253

Keppler, D., Rudigier, J. \& Decker, K. (1970b) Anal. Biochem. 38, 105-114

Keppler, D., Bischoff, E. \& Decker, K. (1970c) Hormones, Lipids and Miscellaneous, vol. 3, pp. 456-460, KargerVerlag, Basel and New York

Lawford, G. R. \& Schachter, H. (1966) J. Biol. Chem. 241, 5408-5418

Leelavathi, D. E., Estes, L. W., Feingold, D. S. \& Lombardi, B. (1970) Biochim. Biophys. Acta 211, 124-138

Lesch, R., Reutter, W., Keppler, D. \& Decker, K. (1970) Exp. Mol. Pathol. 12, 58-69

Lineweaver, H. \& Burk, D. (1934) J. Amer. Chem. Soc. $56,658-666$
Lowry, O. H., Rosebrough, N. J., Farr, A. L. \& Randall, R. J. (1951) J. Biol. Chem. 193, 265-275

Maley, R. W., Hamilton, R. L. \& Lequire, V. S. (1969) J. Lipid Res. 10, 433-439

Mans, R. J. \& Novelli, G. D. (1960) Biochem. Biophys. Res. Commun. 3, 540-543

Medline, A., Schaffner, F. \& Popper, H. (1970) Exp. Mol. Pathol. 12, 201-211

Michell, R. H. \& Hawthorne, J. N. (1965) Biochem. Biophys. Res. Commun. 21, 333-338

Molnar, J., Robinson, G. B. \& Winzler, R. J. (1965) J. Biol. Chem. 240, 1882-1888

Morré, D. J., Merlin, L. M. \& Keenan, T. W. (1969) Biochem. Biophys. Res. Commun. 37, 813-819

Morré, D. J., Mollenhauer, H. \& Bracker, C. E. (1971) in Origin and Continuity of Cell Organelles (Reinert, J. \& Ursprung, H., eds.), pp. 81-126, Springer-Verlag, Heidelberg

Neutra, M. \& Leblond, C. P. (1966) J. Cell Biol. 30, 137-150

Pennington, J. (1961) Biochem. J. 80, 649-654

Rambourg, A., Hernandez, W. \& Leblond, C. P. (1969) J. Cell Biol. 40, 395-414

Reutter, W. (1971) Habilitationsschrift, Universität Freiburg, Germany

Reutter, W. \& Bachmann, W. (1971) Verh. Deut. Ges. Inn. Med. 77, 1177-1178

Reutter, W., Lesch, R., Keppler, D. \& Decker, K. (1968) Naturwissenschaften 55, 497-498

Reutter, W., Keppler, D., Lesch, R. \& Decker, K. (1969) Verh. Deut. Ges. Inn. Med. 75, 363-365

Reynolds, R. D. \& Reutter, W. (1973) J. Biol. Chem. 248, 1562-1567

Schreiber, G., Rotermund, H. M., Maeno, H., Weigand, K. \& Lesch, R. (1969) Eur. J. Biochem. 10, 355-361

Schreiber, G., Urban, J., Zähringer, J., Reutter, W. \& Frosch, U. (1971) J. Biol. Chem. 246, 4531-4538

Shinozuka, H., Farber, J. L., Konishi, Y. \& Anukarahanonta, T. (1973) Fed. Proc. Fed. Amer. Soc. Exp. Biol. 32, 1516-1526

Spiro, M. J. \& Spiro, R. G. (1968) J. Biol. Chem. 243, 6529-6537

Tetas, M., Chao, H. \& Molnar, J. (1970) Arch. Biochem. Biophys. 138, 135-146

Wagner, R. \& Cynkin, M. A. (1969a) Biochem. Biophys. Res. Commun. 35, 139-143

Wagner, R. \& Cynkin, M. A. (1969b) Arch. Biochem. Biophys. 129, 242-247

Wagner, R. \& Cynkin, M. A. (1971) J. Biol. Chem. 246, 143-151 